\title{
Tire Kazirzade (Kaziroğlu) Camii'nin Plan ve Süslemelerine İlişkin Yeni Bulgular $^{\mathrm{a}}$
}

\author{
Onurhan Bozkurt ${ }^{b}$
}

\section{Özet}

Kazirzade Camii, dönemi, mimari yapısı ve süslemeleri ile Tire kentinin önemli dini yapılarından biridir. Kazirzade Camii'nin günümüze ulaşabilen bir inşa kitabesi yoktur ve yapımına da hangi tarihte başlandığı tam olarak bilinmemektedir. Ancak 2015-2016 yılları arasında yapilan restorasyon çalışmaları ile ortaya çıkan bulgular, yapı hakkında daha sağlıklı bilgiler elde etmemizi sağlamıştır. Bu doğrultuda araştırmamızın öncelikli amacı, ortaya çıkan bulgular eşliğinde yapının nasıl bir etkileşim içerisinde olduğu ve hangi dönemde ele alınması gerektiğini vurgulamaktır. Caminin iç ve dış kısımlarında yapılan kapsamlı restorasyon çalışmalarında, yapının plan şeması ve süslemelerine yönelik önemli bulgular elde edilmiştir. Harim içerisinde ortaya çıkan izlerden, yapının orijinalde zaviye odalarına sahip olduğu; ancak bu odaların günümüze gelemediği anlaşılmıştır. Bunun yanı sıra, yapıya ait tuğla ve alçı süslemeler de bu çalışmalar ile ortaya çıkarılmıştır.
Anahtar Kelimeler

Tire

Süsleme

Restorasyon

Tuğla-Alçı

Makale Hakkında

Geliş Tarihi: 09.07.2020

Kabul Tarihi: 26.03 .2021

Doi: $10.18026 /$ cbayarsos.767186

\section{New Findings on the Plan and Decorations of Tire Kazirzade (Kaziroğlu) Mosque}

\begin{abstract}
Kazirzade Mosque is one of the important religious buildings of Tire city in terms of its period, architectural structure and decorations. Kazirzade Mosque doesn't have a construction inscription that survives to the present day, and it isn't known exactly when the construction was started. However, the findings gained in the restoration studies carried out between 2015-2016 have enabled us to obtain more sound information about the structure. In this direction, the primary purpose of this research is to emphasize the interaction that the structure had and the period in which it should be considered in accordance with the findings. In the comprehensive inner and outer restoration works carried out on the mosque, significant findings were obtained regarding the plan scheme and decorations of the structure. It is understood from the traces that emerged in the sanctuary that the building originally had guest rooms which could not survive until today. Besides, the brick and stucco decorations of the building were revealed in these excavations.
\end{abstract}

Keywords

Tire

Decoration

Restoration

Brick-Stucco

About Article

Received: 29.07.2020

Accepted: 26.03.2021

Doi: 10.18026/cbayarsos.767186

\footnotetext{
a Bu çalışma Trakya Üniversitesi 23. Uluslararası Ortaçağ ve Türk Dönemi Kazıları ve Sanat Tarihi Araştırmaları Sempozyumu'nda bildiri olarak sunulmuştur.

b Doktorant, Ege Üniversitesi, Sosyal Bilimler Enstitüsü, Sanat Tarihi Doktora Programı, İzmir/TÜRKIYYE. ORCID: https://orcid.org/0000-0001-82650282, onurhandi@gmail.com
} 


\section{Giriş}

Cami, İzmir' in Tire ilçesinde, Ertuğrul Mahallesi'nde bulunan Kaziroğlu Caddesi üzerinde yer almaktadır. Kitabesi ve vakfiyesi olmayan caminin inşa tarihi bilinmemektedir. Bazı araştırmacılar tarafından 1384 yılında inşa edildiği söylense de (Başaran, 1998, 362), bunun gerçeği yansıtmadığı düşünülmektedir. Çünkü yapıya ait, günümüze ulaşabilen yazılı hiçbir belge yoktur. Ancak, yapının mimari özellikleri ve süslemeleri incelendiğinde, 14. yüzyılda Aydınoğulları Beyliği Dönemi'nde bir zaviye bünyesinde inşa edilmiş olduğu anlaşılmaktadır. Yapı, Osmanlı Dönemi'nde eklenen minare ile mahalle boyutunda hizmet veren bir cami niteliği kazanmıştır. Halk arasında Kadızade, Cazıroğlu gibi adlar ile de anılmaktadır.

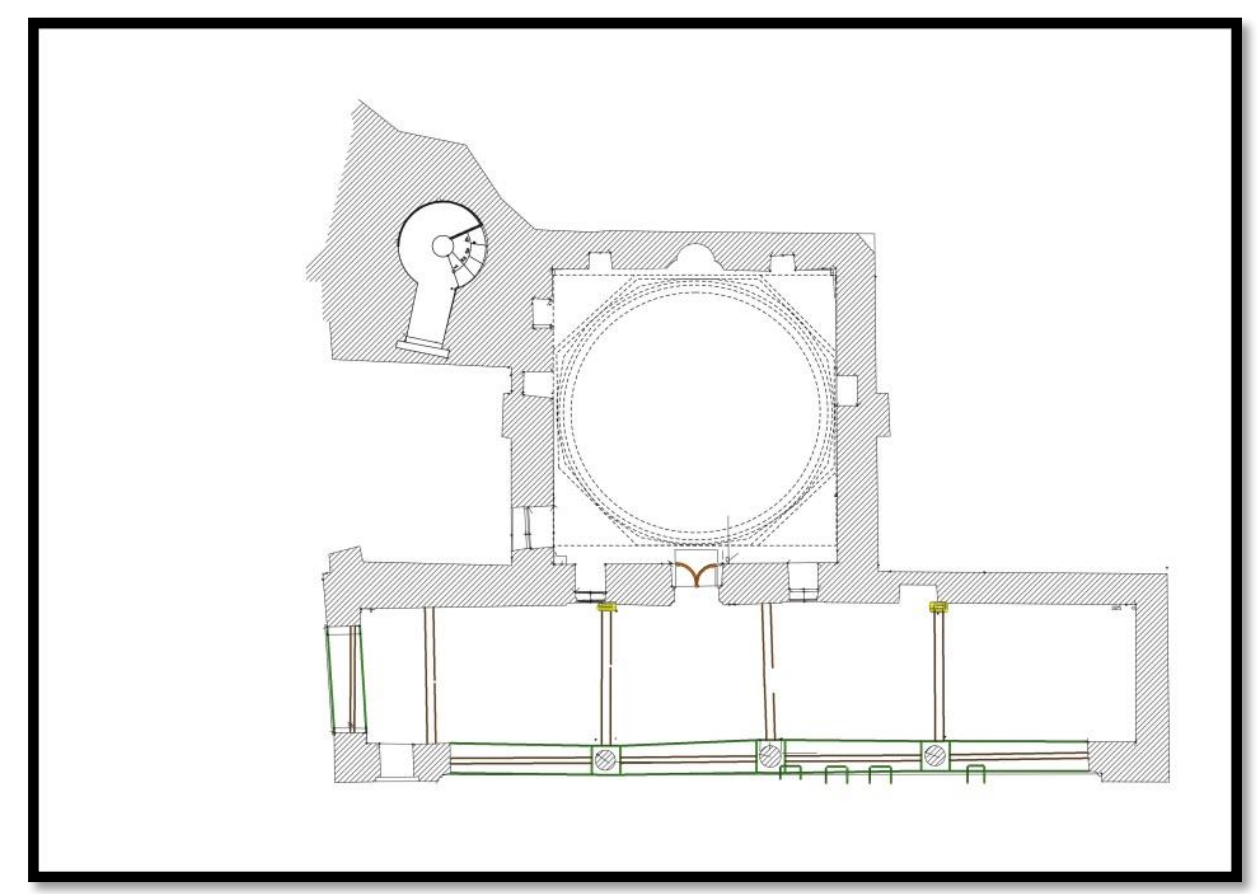

Şekil 1. Tire Kazirzade Camii plan şeması (İzmir Vakıflar Bölge Müdürlüğü Arşivi'nden İşlenerek).

Kare planlı cami, sekizgen yüksek kasnaklı, pandantif geçişli kubbe ile örtülüdür (Tokluoğlu, 1964, 18) (Fot. 1-Şekil 1). Harimin kuzeyindeki dört birimli son cemaat yeri, yanlarda payeler, ortada ise sütunlar üzerine oturmaktadır (Fot. 2). Kuzey cephede, giriş açıklığının doğusunda, batısında ve üstünde olmak üzere, toplamda üç adet yuvarlak kemerli pencere yer alır. Batı taraftaki pencerenin yanına, dikdörtgen formlu diş mihrap yerleştirilmiştir. Caminin doğusunda bulunan alana, yapıdan bağımsız beş hücreli bir medrese inşa edilmiştir. Camide inşa malzemesi olarak moloz taş ve tuğlanın kullanıldığı görülür (Yapı hakkında bkz. Tokluoğlu, 1964, 18; Aslanoğlu, 1978, 11-14; Kalfazade, 1995, 399-403; Armağan, 2003, 216; Yüksel, 2014, 38). 


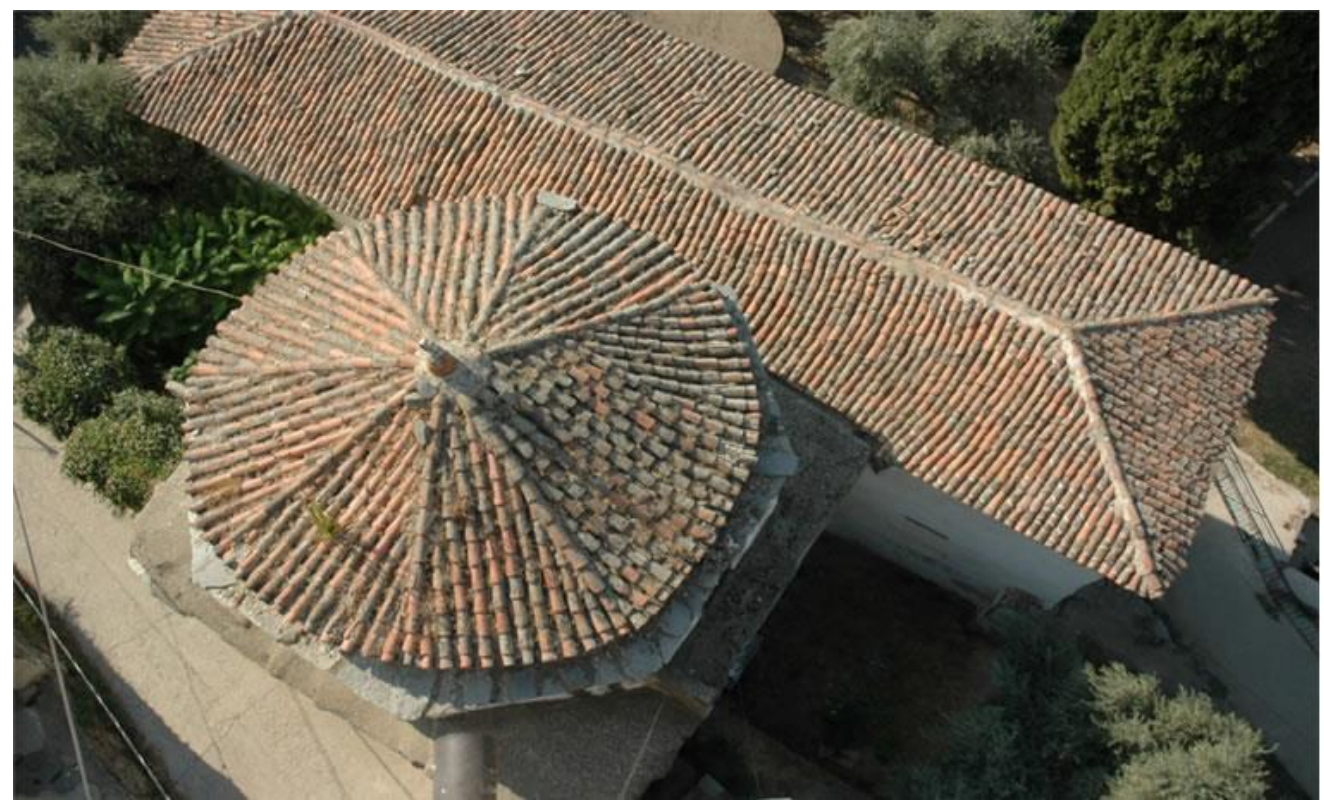

Fot. 1. Tire Kazirzade Camii genel görünüm (www.piramitdekorasyon.net, Erişim Tarihi: 06. 12. 2020).

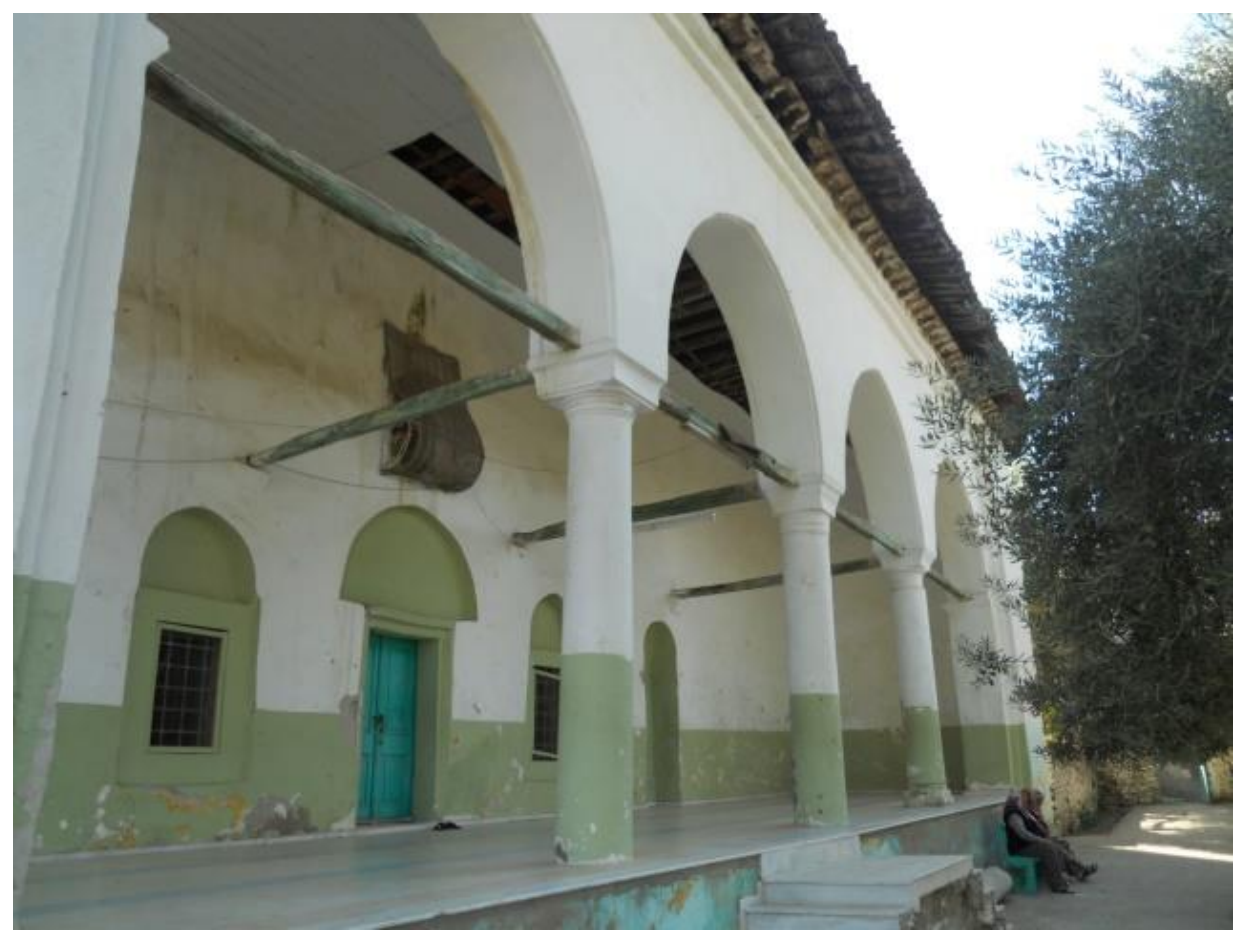

Fot. 2. Restorasyon çalışmaları öncesi caminin kuzey cephesinden görünüm (Fotoğraf: Şakir Çakmak, 2016)

2015-2016 yılları arasında gerçekleştirilen restorasyon çalışmaları ile yapının plan ve süslemelerine ilişkin yeni bulgular ortaya çıkmıştır. 


\section{Caminin Planına İlişkin Yeni Bulgular}

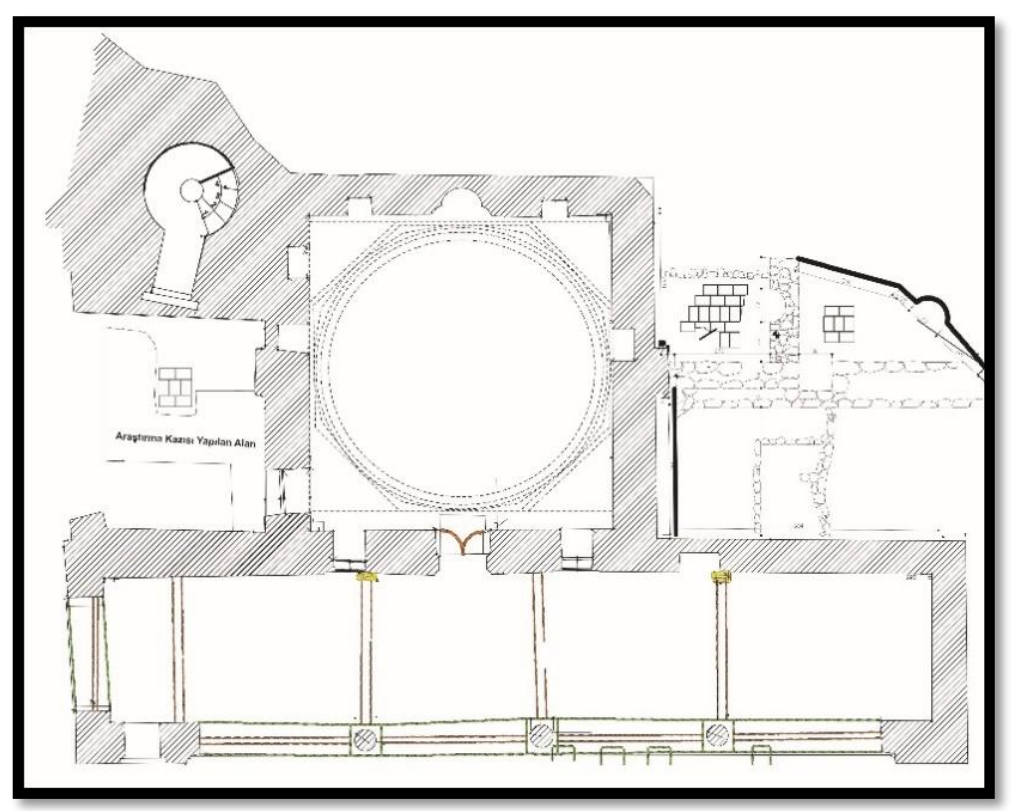

Şekil 2. Restorasyon çalışmaları sonucunda, caminin doğu ve batısında ortaya çıkarılan zaviye odalarına ilişkin duvar kalıntıları (İzmir Vakıflar Bölge Müdürlüğü Arşivi'nden İşlenerek).

Kazirzade Camii'nde yapılan temel araştırmalarında, caminin doğu ve batı bölümünde zaviyeye ait çeşitli mekanların temelleri ortaya çıkmıştır (Şekil 2). Her iki yanda yer alan bu mekanlara ulaşım, cami içerisindeki açıklıklar ile sağlanmıştır.

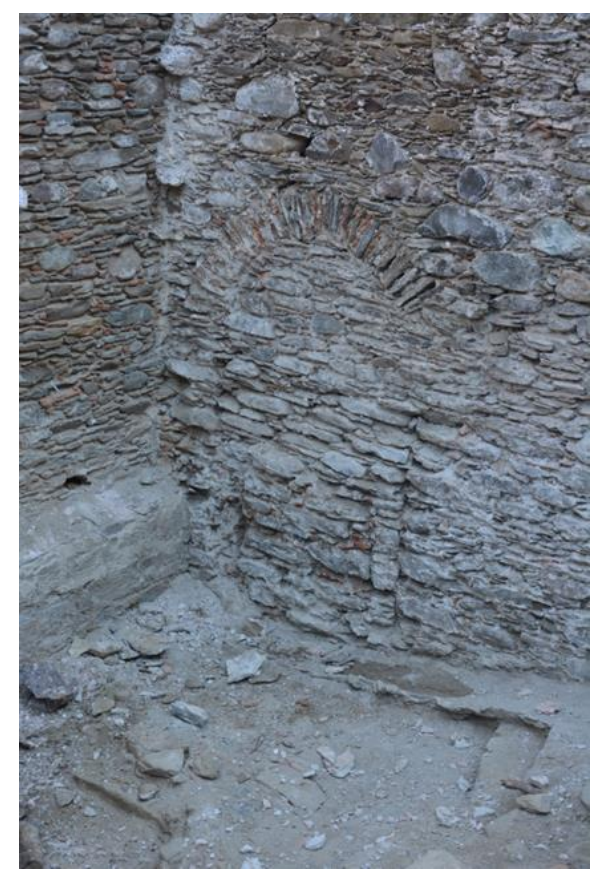

Fot. 3. Batıdaki zaviye odalarına harimden girişi sağlayan açılık (Fotoğraf: Onurhan Bozkurt, 2016). 


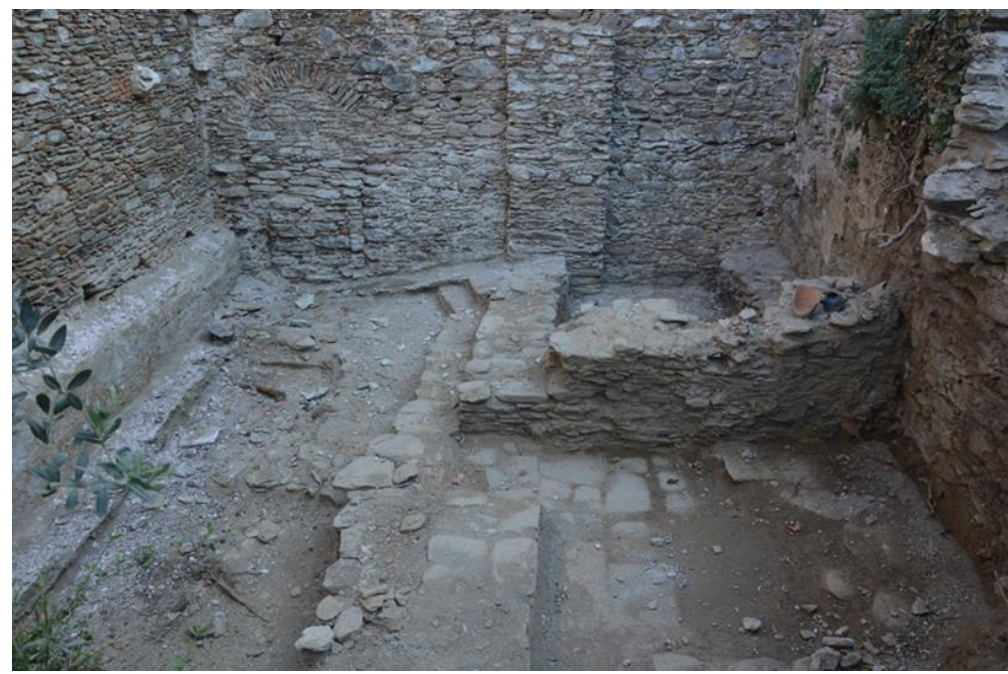

Fot. 4. Batı bölümde ortaya çıkan zaviye odaları (Fotoğraf: Onurhan Bozkurt, 2016).

Batı bölümde yer alan zaviye odalarına giriş, caminin batı cephesinin kuzey kesimindeki sivri kemerli bir açıklık ile sağlanmıştır (Fot. 3). Bu açıklık ile ilk olarak doğu-batı yönünde uzanan geçiş mekanına, ardından ise geçişin güneyindeki zaviye odalarına ulaşılmaktadır (Fot. 4). Batı duvarının ortasında yer alan dikdörtgen kesitli gömme ayak, geçiş mekanı ile odaların sınırlarının net bir şekilde algılanmasını sağlamaktadır. Caminin batı duvarına bitişik durumdaki ilk zaviye odası, kare planlı düzgün bir plan şemasına sahip iken; bunun batısındaki ikinci oda, güneyden geçen yola göre inşa edilmiştir. Bu durum, ikinci odanın plan şemasının yamuk olmasına neden olmuştur (Çakmak, 2016, 2).

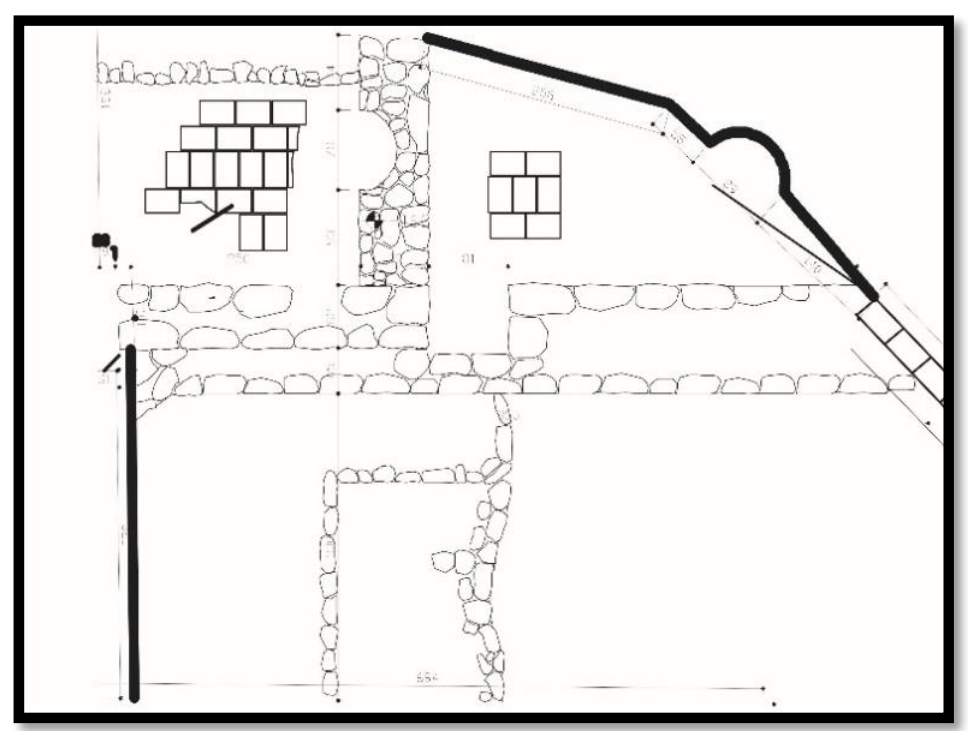

Şekil 3. Batı bölümde yer alan zaviye odalarına ait duvar kalıntıları (İzmir Vakıflar Bölge Müdürlüğü Arşivi'nden İşlenerek).

Zaviye odalarına ait duvar kalıntıları incelendiğinde; bu odaların inşasında, moloz taş ve yer yer tuğlanın kullanıldığı anlaşılmaktadır. $\mathrm{Bu}$ alanda görülen tuğlalar, $35 \times 23 \mathrm{~cm}$. 
boyutlarındadır. Her iki odaya birer adet ocak yerleştirilmiştir. Ocağın bulunduğu duvarın kalınlığı 69 cm. iken; odaları birbirinden ayıran ana duvarın kalınlığı, 107 cm.'dir (Şekil 3). Duvarlarda kubbe ya da tonoz izlerinin bulunmaması, bu odaların düz tavanla örtülü olabileceğini düşündürmektedir.

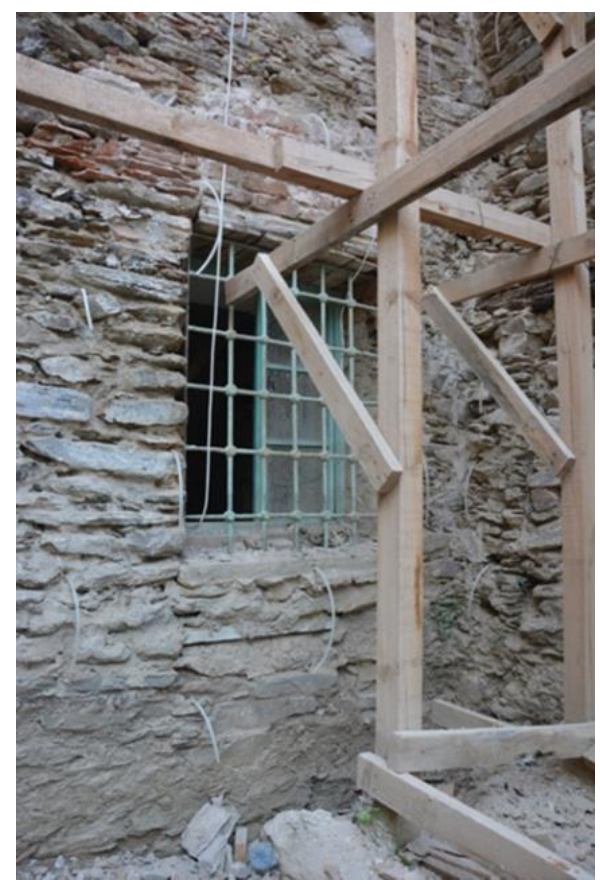

Fot. 5. Doğudaki zaviye odasına harimden girişi sağlayan açılık (Fotoğraf: Onurhan Bozkurt, 2016).

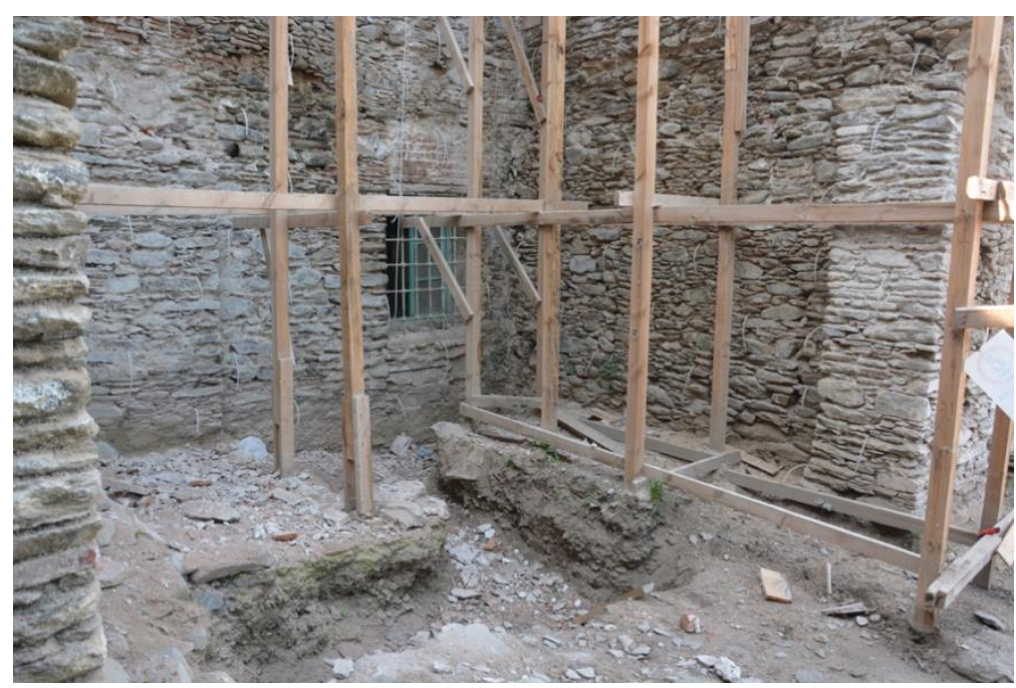

Fot. 6. Doğu bölümde ortaya çıkan zaviye odaları (Fotoğraf: Onurhan Bozkurt, 2016).

Doğu bölümde yer alan zaviye odalarına giriş, harim doğu duvarının kuzey ve güney kesimlerinde yer alan sivri kemerli birer açıklık ile sağlanmıştır (Fot. 5). Bu açıklık ile kuzeygüney yönünde uzanan, yan yana konumlandırılmış iki odanın bulunduğu bölüme geçilmektedir (Fot. 6). Kuzeydeki zaviye odasına, harimin yanı sıra, son cemaat yerinin doğusunda bulunan bir açıklık vasıtasıyla da girilebilmektedir. Sıva raspası ile ortaya 
çıkartılan bu bölümün hemen üzerindeki izlerden, bir adet pencerenin de olduğu anlaşılmıştır. Ancak bu açıklıklar (son cemaat yeri doğu duvarında bulunan), zaviye odalarının işlevini yitirdiği dönemde, moloz taş dolgu malzemeyle kapatılmıştır. Batı bölümde yer alan zaviye odalarında olduğu gibi doğu bölümün ortasında da bir gömme ayak mevcuttur.

Duvarların, moloz taş ve yer yer kullanılan tuğla malzeme ile inşa edildiği görülür. Bu alanda görülen tuğlalar, $35 \times 23 \mathrm{~cm}$. boyutlarındadır. Bu bölümde yer alan odalar, batıdaki odalara oranla daha fazla zarar görmüş ve bu durum, odaların plan şeması hakkında net bir şey söylemeyi güçleştirmiştir. Hasarın meydana gelmesindeki temel sebeplerden biri, zaviye odalarının bulunduğu bölüme yakın bir alana inşa edilen minaredir (Çakmak, 2016, 2).

\section{Caminin Süslemelerine İlişkin Yeni Bulgular}

Sıva raspaları sonucunda camide, alçı ve tuğla olmak üzere iki tür süsleme ortaya çıkartılmıştır. Tuğla süsleme, caminin son cemaat yeri kemer yüzeylerinde, alçı süsleme ise kubbe elemanlarında kullanım alanı bulmuştur.

Restorasyon çalışmaları sonucunda, harimin kuzeyinde yer alan son cemaat yerinin kemer yüzeylerinde tuğla süslemeler ortaya çıkmıştır. İki yanda yer alan kemer köşeliklerinin yüzeyinde, tuğlaların yatay ve dikey formda, alternatifli şekilde yerleştirilmesiyle meydana gelen süslemeler görülür.

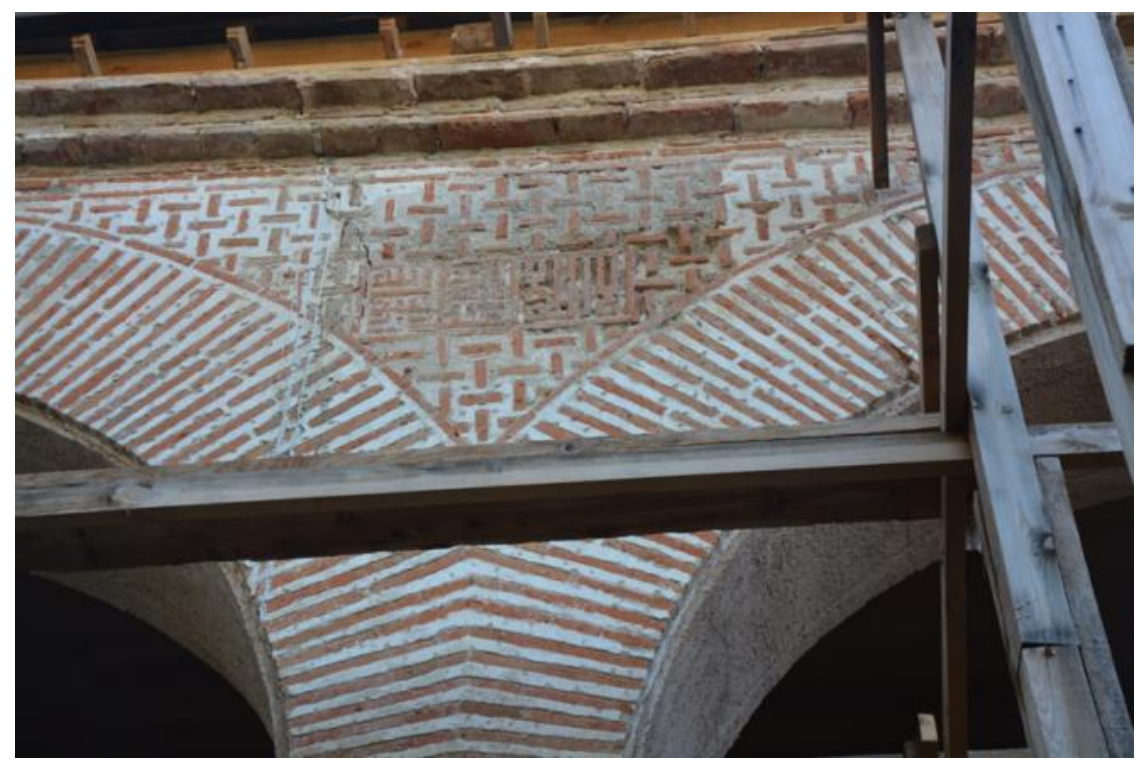

Fot. 7. Son cemaat yeri kemer yüzeyindeki makili tekniği ile yazılmış “Kelime-i Tevhid” (Fotoğraf: Onurhan Bozkurt, 2016).

Son cemaat yeri kemer yüzeyinin batısında yer alan panonun içinde, makıli tekniği ile yazılmış "Kelime-i Tevhid" yer almaktadır (Fot. 7-Çiz. 1). Sırsız tuğlaların belirli bir düzende yerleştirilmesi ile oluşturulan harflerin büyük bir bölümü, zarar görmüş durumdadır. Orta bölümde ise iki yandan belirli bir düzen doğrultusunda gelen zikzaklı tuğlaların meydana getirdiği balıksırtı motifinde süslemeler bulunmaktadır (Fot. 8-Çiz. 2). 


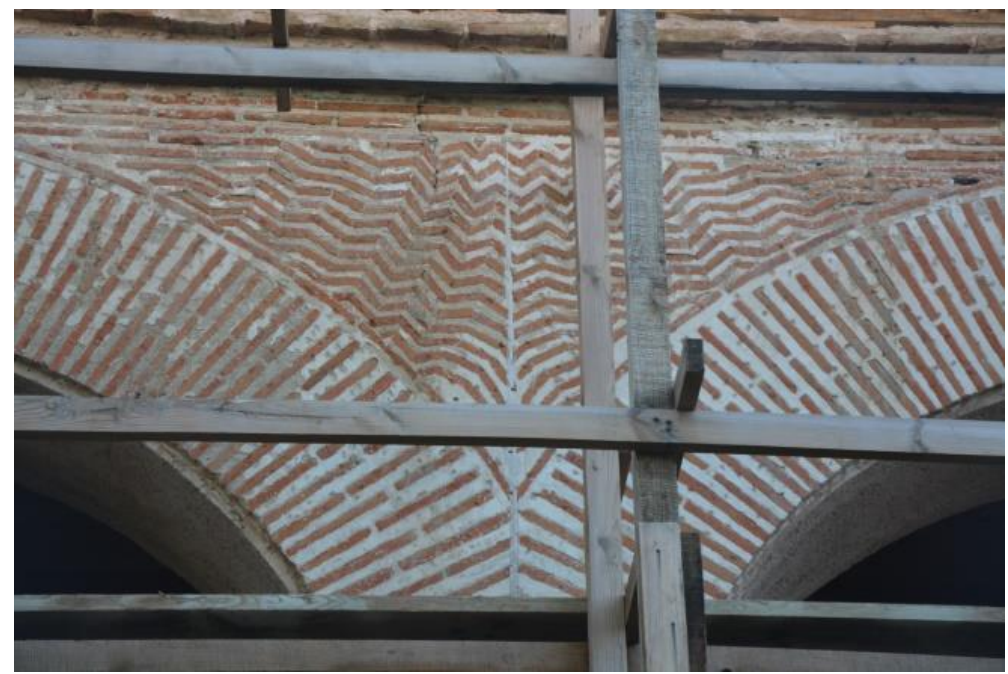

Fot. 8. Son cemaat yeri, orta bölümde yer alan zikzak süslemeler (Fotoğraf: Onurhan Bozkurt, 2016).

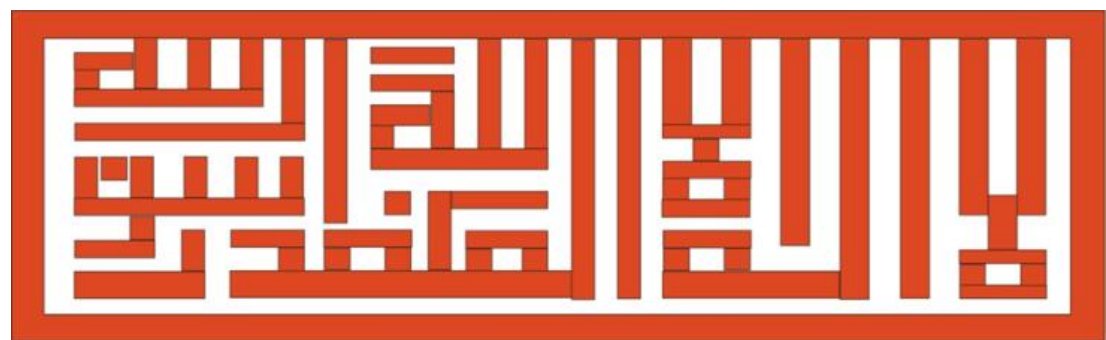

Çiz. 1. Son cemaat yeri kemer yüzeyindeki makili tekniği ile yazılmış "Kelime-i Tevhid" (Çizim: Onurhan Bozkurt).

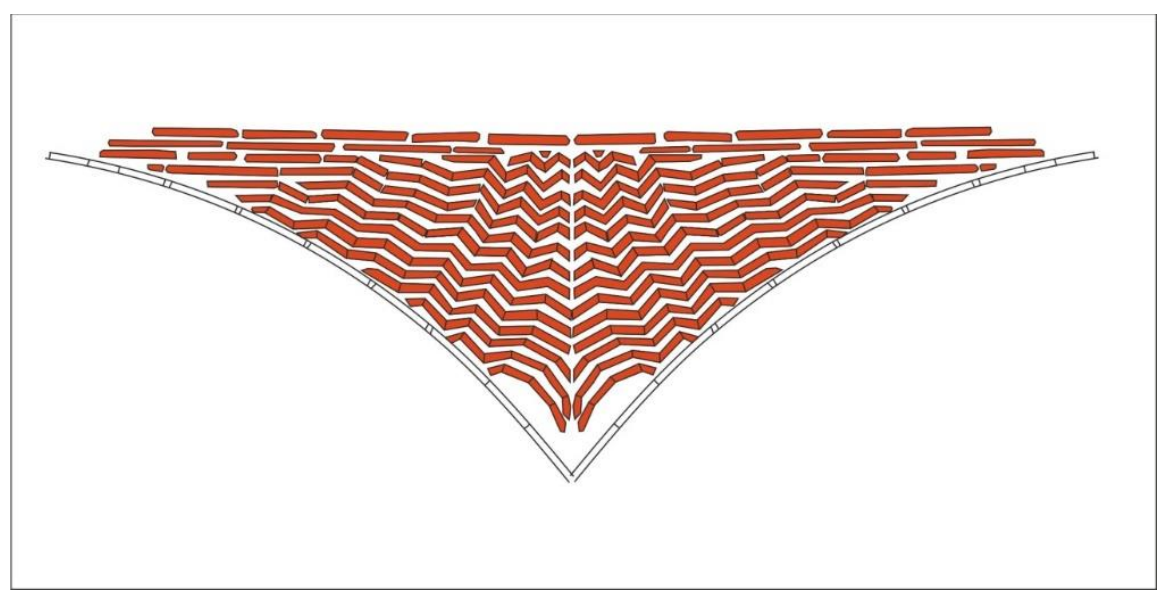

Çiz. 2. Son cemaat yeri, orta bölümde yer alan zikzak süslemeler (Çizim: Onurhan Bozkurt).

Harimin güneydoğu köşesinde yer alan pandantif üzerinde, daha önce varlığını bilmediğimiz sıva raspaları sonrası ortaya çıkan, kalıplama tekniğiyle yapılmış alçıdan bitkisel süslemeler yer almaktadır (Fot. 9). Pandantifin süsleme düzenini; palmet, rumi ve kıvrım dallar oluşturur. 
Bugün alt bölümü tahrip olmuş süslemenin, yalnızca üst kısmındaki motifler seçilebilmektedir. Kalan izlerden, iki yana iri yarım palmetlerin yerleştirildiği, ortada kalan alana ise kıvrım dallar ile birbirine bağlanmış rumilerin çevrelediği palmetlerin işlendiğ görülmektedir. Üstteki palmet motifi, rumilerle çevrelenerek bir kalp motifi şeklinde verilirken, alttaki daha küçük boyutlu palmet, keskin hatlı bir baklava dilimi içine yerleştirilmiştir. Bugün tahrip olmasına karşın, yanlardaki iri palmetlerin hatlarının devam şeklinden, ortada, zemine doğru devam eden tam bir palmet ile süslemenin sonlandırıldığını düşünmek mümkündür (Çiz. 3) (Bozkurt, 2016, 192). Sonraki dönemlerdeki onarımlarda, süsleme sıvayla kapatılmış, sıva iyi tutsun diye de süslemenin yüzeyi çentiklenmiştir (çekiçleme).

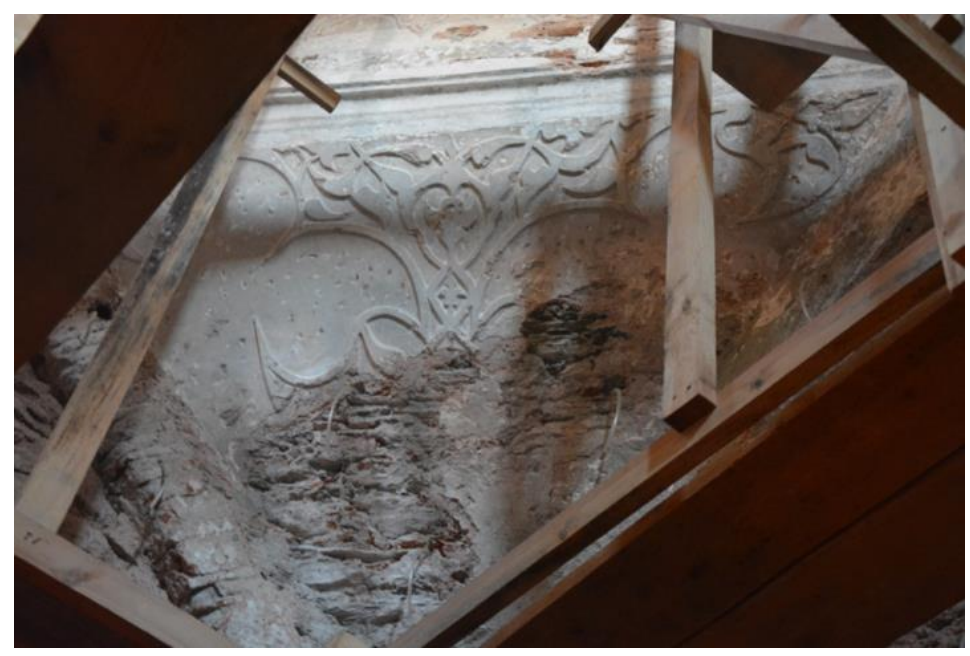

Fot. 9. Kubbenin güneydoğu pandantifinde yer alan süslemeler (Fotoğraf: Onurhan Bozkurt, 2016).

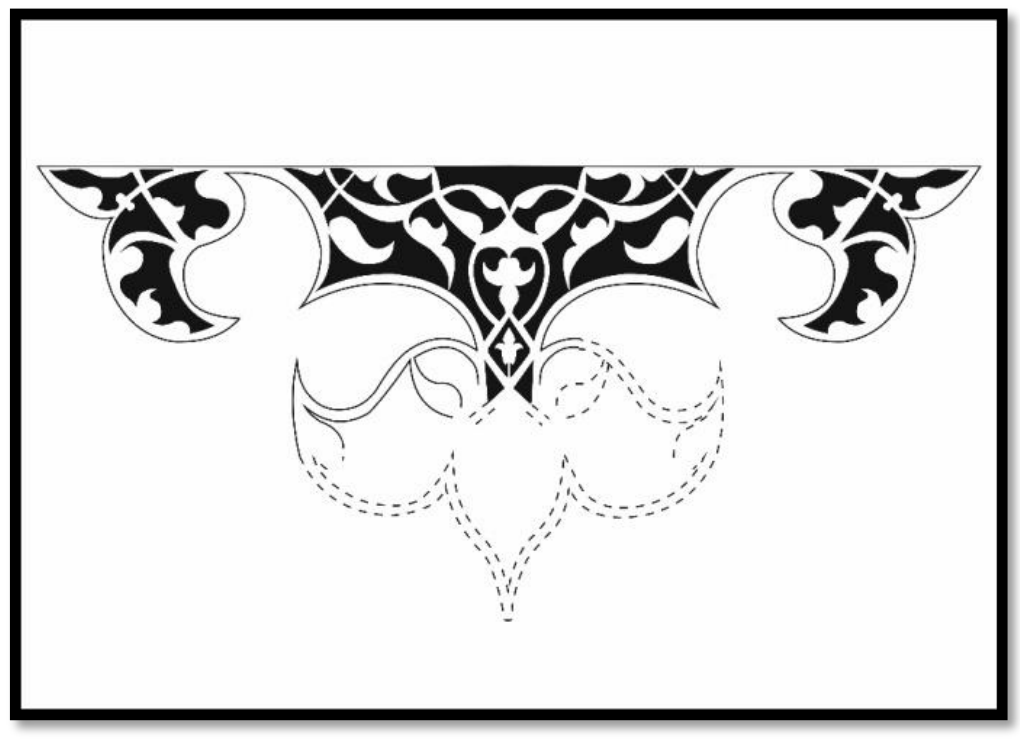

Çiz. 3. Kubbenin güneydoğu pandantifinde yer alan bitkisel süslemenin tamamlanmış hali (Çizim: Onurhan Bozkurt).

Güneybatı pandantifi üzerinde, yine alçı kalıplama tekniğiyle yapılmış olan bezemeler, az da olsa seçilebilmektedir. Ancak bu alandaki sıvanın neredeyse tamamı bozulduğu için, süslemenin kapsamı tam olarak anlaşılamamaktadır. Muhtemelen bu ve diğer iki pandantif 
de, güneydoğu köşede yer alan pandantif gibi süslemelidir. Ancak bu süslemeler günümüze ulaşamamıştır.

Kubbe kasnă̆ı üzerinde, kalıplama tekniği ile yapılmış, kasnağı bir şerit halinde çevreleyen yüzeysel mukarnaslı süslemeler görülmektedir (Fot. 10). İki kademeli olan bu mukarnasların, kenar hatları belirgin hale getirilmiştir. Ancak bu süslemelerin bir kısmı, hasar gördüğü için günümüze kadar gelememiştir.

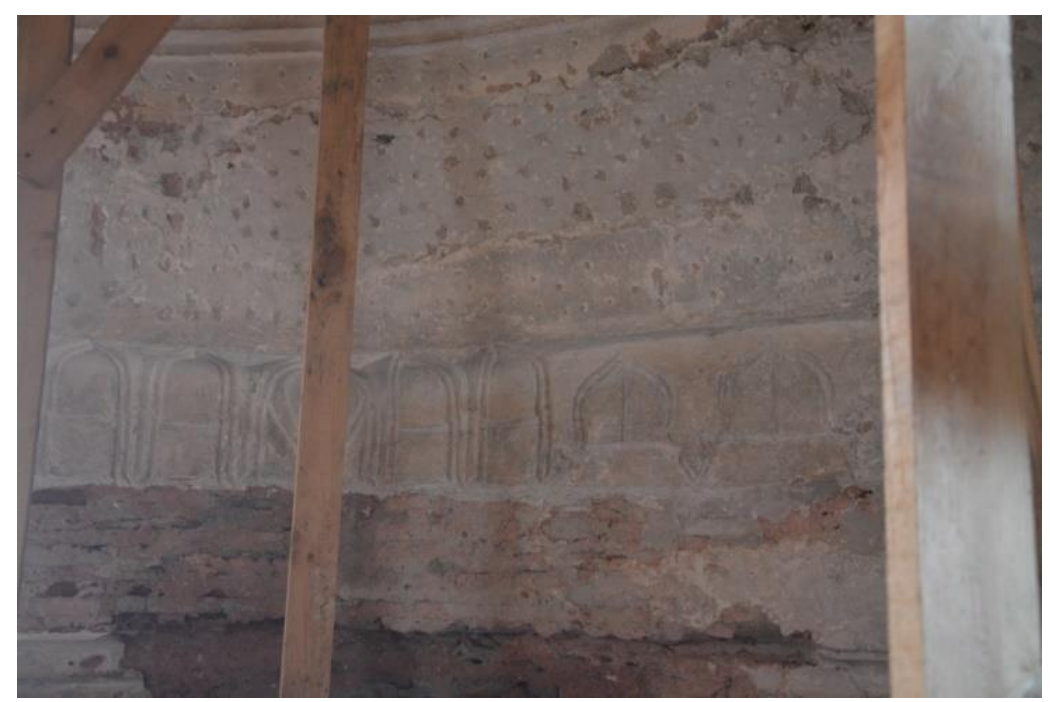

Fot. 10. Kubbe kasnağında yer alan yüzeysel mukarnaslar (Fotoğraf: Onurhan Bozkurt, 2016).

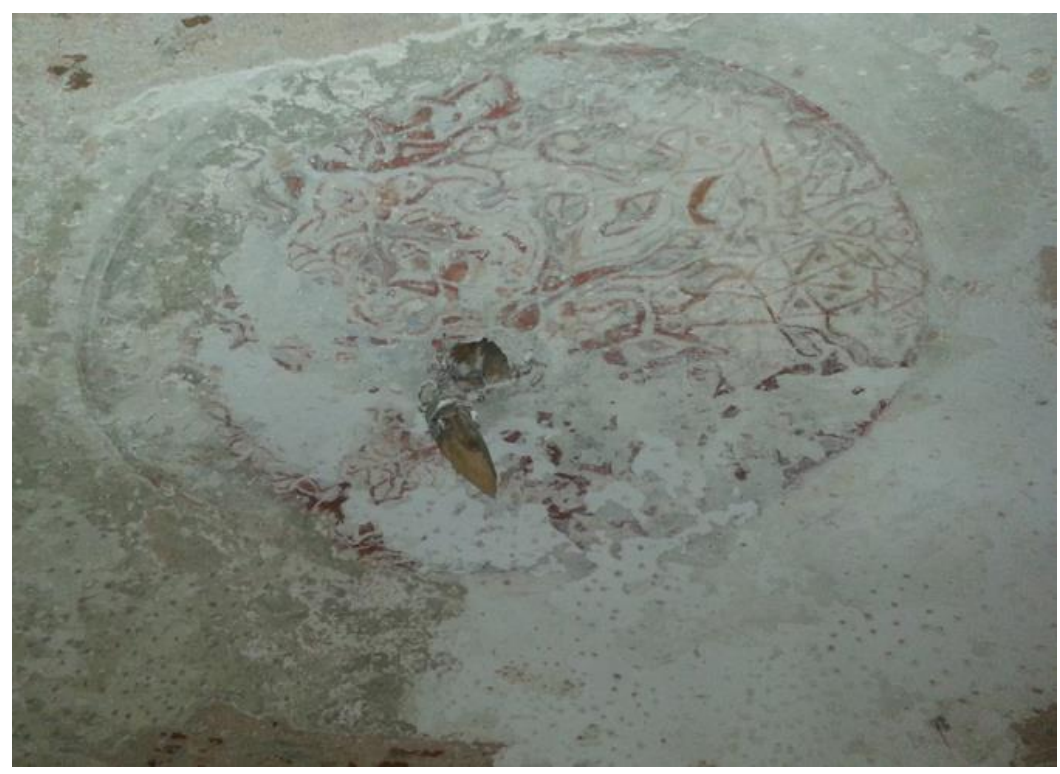

Fot. 11. Kubbe göbeğinde yer alan kalem işi süsleme (Fotoğraf: Onurhan Bozkurt, 2016).

Yapılan raspa çalışmaları sonrasında kubbe göbeğinde, kalem işi ile oluşturulmuş bitkisel süslemeli madalyon ortaya çıkmıştır (Fot. 11). Bu bitkisel süslemenin, farklı dönemlerde müdahaleye uğramış olması, yüksek bir ihtimal olarak görülmektedir. Madalyonun özgünde, 
iç içe geçmiş kıvrım dallar üzerinde yer alan palmetlerden meydana gelen bir süslemeye sahip olduğu ancak bir dönem eksilen kısımlarının tamamlanması amacıyla, kötü bir müdahaleye maruz kaldığı anlaşılmaktadır. Süslemeli tabaka, kubbe sıvalarının yenilendiği bir onarım sırasında, sıvanın yüzeye tutturulabilmesi amacıyla yapılan çentikleme (çekiçleme) işlemi nedeniyle zarar görmüştür.

\section{Sonuç}

2015-2016 yılları arasında gerçekleştirilen restorasyon çalışmalarında, yapının plan ve süslemelerine ilişkin önemli yeni bulgular elde edilmiştir. Yapılan bu çalışmalar ile caminin doğu ve batı bölümünde yer alan zaviye odalarına ait temeller, gün yüzüne çıkartılmıştır. Zaviye odalarında ortaya çıkan verilerden hareketle yapının ilk aşamada, bir zaviyenin mescidi olarak inşa edildiği ve iki yanında yer alan zaviye odaları ile bağlantılı olduğu anlaşılmıştır. Ancak, bölgede iskân politikasının tamamlanmasının ardından, zaviye odalarının işlevini yitirdiği düşüncesi akla gelmektedir.

Zaviyeli camiler, toplumda sosyal düzenin sağlanması, yeni iskân alanları yaratılması ve ticaretin gelişmesine katkı sağlaması için tasarlanan yapı gruplarıdır (Acar, 2013, 319). Bunun yanı sıra, ahiler ve gezici dervişler için inşa edilmiş, dini işlevlerinin yanı sıra sosyal amaçlara da hizmet eden önemli yapılardır. Beylikler Dönemi'nde zaviyeler, yerleşik yaşama geçme kaygısındaki Anadolu beyliklerinin, yeni iskân alanları yaratabilmek amacıyla yararlandıkları bir örgütlenme modelidir. Bünyesinde zaviye şeyhine ait bir odanın yanı sıra, toplantı odaları, atölyeler, mutfak, mescit gibi yapı gruplarını da barındırır. Bu bağlamda, Erken Osmanlı Dönemi'nde inşa edilmiş imaretler de zaviyeli camilerin genel şemasına uygun şekilde avlu, ibadet ve zaviye mekanları ile birlikte tasarlanmıştır. Bu dönemde sevilerek kullanılan zaviye plan şeması, Bilecik Orhan Gazi İmareti (1335-1339) (Eyice, 1963, 67), Bursa Hüdavendigar İmareti (1362-1385) (Acar, 2011, 68-94), İznik Nilüfer Hatun İmareti (1388) (Eyice, 1957, 107 110), Milas Firuz Bey İmareti (1396) (Acar, 2013, 321), Afyon Gedik Ahmet Paşa İmareti (1472) (Tanman, 1996, 545) gibi yapılarda karşımıza çıkar. Tire kentinde ise Tire Kazirzade Camii dışında sadece Tire Yahşi Bey İmareti (1441) (Kuban, 2007, 120), zaviyeli plan şemasına sahip cami olarak dikkati çeker.

Yakın zamanda yapılan restorasyon çalışmaları, plan şemasının yanı sıra süslemelere ilişkin de önemli veriler sunmuştur. Özellikle son cemaat yeri ve harim içerisinde yapılan raspa çalışmaları ile birlikte, alçı ve tuğla süslemeler ortaya çıkartılmıştır.

Sıvı haldeki alçının, önceden hazırlanmış negatif bezemeli kalıpların içine dökülüp kurutulmasıyla meydana getirilen kalıplama tekniği, her dönemde yoğun olarak tercih edilmiş bir tekniktir. Hem seri üretim imkanı vermesi hem de zamandan tasarruf sağlaması, alçı süslemede bu tekniğin kullanımını yaygınlaştırmıştır. Özellikle 14. ve 15. yüzyıllarda alçıdan süsleme yapımı, bir moda gibi yaygınlaşmış ve bu moda Tire kentinde yoğun bir biçimde kendini hissettirmiştir. Bu bağlamda Beylikler Dönemi'ne ait alçı süslemeli örnekler sadece Aydınoğulları Dönemi'ne ait yapılarda karşımıza çıkmaktadır. Kazirzade Camii'nin dişında Yayla Fakih Camii ve Çanakçı Mescidi (1338) (Aslanoğlu, 1978, 82-83), gerek alçı süsleme gerekse kalıplama tekniğinin kullanıldığı yapılar olmasıyla önem taşımaktadır. Bu yapılar arasında en yoğun alçı süsleme, Tire Yayla Fakih Mescidi'nde karşımıza çıkar (Gürhan, Demiralp, Çakmak ve Daş, 2008, 324-331). 
Tire Kazirzade Camii'nin kubbe kasnağında gördüğümüz kalıplama teknikli yüzeysel mukarnas şeridi, aynı şekilde Tire Çanakçı Mescidi'nin kubbe kasnağında da kullanım alanı bulmuştur. Tire Kazirzade Camii'nin kubbe geçişlerinde karşılaştığımız bitkisel motifli alçı süsleme, farklı bir yorumlama ile Tire Yayla Fakih Mescidi'nin kubbe geçişlerine de uygulanmıştır. Bu süslemelerde gördüğümüz benzerlikler, bize Tire'de alçı süsleme alanında bir atölye birliğinin olduğunu gösterir niteliktedir.

Sırsız tuğlaların çeşitli formlarda yerleştirilmeleriyle meydana getirilen süsleme, Beylikler Dönemi'nde sıklıkla tercih edilen diğer bir süsleme türüdür. Zikzak, baklava, svastika ve sarmal gibi onlarca deseninin oluşturulabildiği bu teknik, özellikle tuğla minarelerin ve kemer yüzeylerinin vazgeçilmez süsleme unsurlu olmuştur.

Sırsız tuğla süsleme, Beylikler Dönemi'nde en yoğun Aydınoğulları Beyliği'nde kullanım alanı bulmuştur. Tire Kazirzade Camii'nin yanı sıra Birgi Ulu Cami (1312) (Eroğlu, 2006, 99-100), Birgi Aydınoğlu Mehmed Bey Türbesi (1334) ve Selçuk İsa Bey Camii (1374-75) (Ogan, 2006, 78) sırsız tuğla malzemenin uygulama alanı bulduğu yerlerdir. Saruhanoğulları Beyliği'nde Manisa Ulu Cami (1366) (Acun, 1995, 130), Germiyanoğulları Beyliği'nde Kütahya Kurşunlu Cami (1377-78) (Bozkurt, 2016, 77-78) ile Menteşeoğulları Beyliği'nde Turgut İlyas Bey Camii (1311) (Duran, 1999, 128-129), sırsız tuğla süslemeli örnekleri teşkil eder.

Germiyanoğulları Beyliği'ne ait Kütahya Kurşunlu Cami'nin son cemaat yeri kemer yüzeylerinde görülen zikzak süslemeler, 2015 yılında yapılan restorasyonlar ile gün yüzüne çıkartılmıştır. Taş ve tuğla malzemenin bir arada kullanılması ile meydana getirilen zikzaklı süslemeler, Tire Kazirzade Camii'nin son cemaat yerinde gördügümüz sırsız tuğla malzemeli zikzak süslemeler ile benzerlik göstermesi açısından önemlidir.

Tire'nin demografik yapısı göz önünde bulundurulduğunda, kentte 14. yüzyılda yoğun bir Yahudi nüfusunun varlığı dikkat çekmektedir (Çakmak, 2019, 17-19). Bu dönemde, kent içerisindeki Türk nüfusunu yaygınlaştırmaya yönelik çeşitli iskân politikalarının uygulandığ bilinmektedir. Bu bağlamda, kentin çeşitli noktalarına zaviyeli yapılar inşa edilerek, Türk nüfusunu belli noktalara yerleştirmek amaçlanmıştır. Tire Kazirzade Camii'nin de, söz konusu politikanın sonucunda inşa edilmiş yapılardan birisi olması, yüksek ihtimal olarak görülebilir. Yapının inşa edildiği bölüm ve güney hatt1, 14. yüzyılda Türk nüfusunun yoğunlaşmaya başladığı noktalardandır. Öncesinde bölgede hâkim olan Yahudi nüfusu, Tire Kazirzade Camii, Tire Yahşi Bey İmareti gibi zaviyeli yapılar ile yerini Türk nüfusuna bırakmaya başlamıştır.

\section{Kaynakça}

Acar, T. (2011). Anadolu Türk Mimarisinde Tabhaneli Camiler, (Yayımlanmamış Doktora Tezi) Ege Üniversitesi, Sosyal Bilimler Enstitüsü, İzmir. Erişim Adresi: https://tez.yok.gov.tr/UlusalTezMerkezi.

Acar, T. (2013). “Tabhaneli Camilerin Tipolojisi Üzerine Bir Deneme”, Süleyman Demirel Üniversitesi Fen Edebiyat Fakültesi Sosyal Bilimler Dergisi. Sayı 28, (s. 303-326). Isparta: Süleyman Demirel Üniversitesi.

Acun, H. (1995). “Manisa İshak Çelebi Külliyesi”, Vakıflar Dergisi, Cilt 19, (s. 127-146) Ankara: T.C. Vakıflar Genel Müdürlüğü.

Armağan, M. A. (2003). Devlet Arşivlerinde Tire. İzmir: Karınca Matbaacılık. 
Aslanoğlu, İ. (1978). Tire'de Camiler ve Üç Mescit. Ankara: Orta Doğu Teknik Üniversitesi Mimarlık Fakültesi Yayınları.

Başaran, M. (1998). “Tire' de Bulunan Camiler ve Temettuat Defterlerine Göre Görevliler ve Mal Varlıkları" Çağdaş Türkiye Tarihi Araştırmaları Dergisi. Cilt 3, (s. 359-383). İzmir: Dokuz Eylül Üniversitesi.

Bozkurt, O. (2016). Osmanlı Beyliği Dışında Batı Anadolu Beyliklerinde Mimari Süsleme. (Yayımlanmamış Yüksek Lisans Tezi) Ege Üniversitesi, Sosyal Bilimler Enstitüsü, İzmir. Erişim Adresi: https://tez.yok.gov.tr/UlusalTezMerkezi.

Çakmak, Ş. (2016). Tire Kazirzade Camisi Sıva Raspası ve Temel Araştırmalarına İlişkin Sanat Tarihi Raporu. (Restorasyon Raporu).

Çakmak, Ş. (2019). "Tire Yalınayak Hamamı Restorasyonu ve Yapıya İlişkin Yeni Bulgular", Sanat Tarihi Dergisi, 28 (1), (s. 1-21). İzmir: Ege Üniversitesi.

Duran, R. (1999). “Turgut (Leyne) İlyas Bey Camii”, Prof. Dr. İsmail Aka Armağanı. (Editörler: Nejdet Bilgi, Mehmet Ersan, Turan Gökçe). (s. 121-134). İzmir: Beta Basım Yayın.

Eroğlu, S. (2006). Batı Anadolu Beylikleri Mimarisinde Tipolojiye Bağlı Süsleme Tasarımları, (Yayımlanmamış Doktora Tezi) Mimar Sinan Üniversitesi, Sosyal Bilimler Enstitüsü, İstanbul. Erişim Adresi: https://tez.yok.gov.tr/UlusalTezMerkezi.

Eyice, S. (1958). “İki Türk Abidesinin Mahiyetleri Hakkında Notlar İznik'te Nilüfer Hatun İmareti ve Kayseri'de Köşk Medrese”, Yıllık Araştırma Dergisi. Sayı: 2, (s. 107-114). Ankara: Ajans- Türk Matbaası.

Eyice, S. (1963). "İlk Osmanlı Devrinin Dini-İçtimai Bir Müessesesi Zâviyeler ve ZâviyeliCamiler" İstanbul Üniversitesi İktisat Fakültesi Mecmuası, Cilt 23, Sayı: 1-2, (s. 1-80). İstanbul: İstanbul Üniversitesi.

Gök Gürhan S., Demiralp, Y., Çakmak, Ş., Daş, E. (2008). “Mimari ve Süsleme Özellikleri ile Tire Yayla Fakih Mescidi", Türk Kültüründe Tire-II Sempozyum Bildirileri 17-19 Kasım 2006. (Yayına Hazırlayanlar: Mehmet Şeker, Arzu Taşcan). (s. 319-341). İzmir: Tire Belediyesi Yayınları.

Kalfazade Ertuğrul, S. (1995). Anadolu'da Aydınoğulları Dönemi Mimarisi (Yayımlanmamış Doktora Tezi) İstanbul Üniversitesi, Sosyal Bilimler Enstitüsü, İstanbul. Erişim Adresi: https://tez.yok.gov.tr/UlusalTezMerkezi.

Kuban, D. (2007). Osmanlı Mimarisi. İstanbul: Yem Yayınları.

Ogan, A. (2006). "Aydınoğullarından İsa Bey Cami'i" Vakıflar Dergisi. Sayı: 3, (s. 73-106). Ankara: T.C. Vakıflar Genel Müdürlüğü.

Tanman, M. Baha (1996). “Gedik Ahmed Paşa Külliyesi”, TDV İslam Ansiklopedisi. Cilt 13, (s. 544-547). İstanbul: TDV İslam Araştırmaları Merkezi Yayınları.

Tokluoğlu, F. (1964). Tire. Tire: Şehir Matbaası.

Yüksel, Caner Ç. (2014). “Aydınoğulları'ndan Osmanlı'ya Tire Külliyeleri (14. - 16. Yüzyıllar)”. Hacettepe Üniversitesi Türkiyat Araştırmaları Dergisi. Sayı: 21, (s. 7-39). Ankara: Hacettepe Üniversitesi Hastaneleri Basımevi. 